\title{
ENTOPARASITES ENCOUNTERED IN SOME FRUIT TREES (REGION OF SOUTH ALBANIA)
}

\author{
Lavdi Hasani \\ Department of Biology \\ University Eqrem Çabej \\ Rruga Studenti 30, Gjirokastër, Albania, 6000 \\ hasanilavdi@yahoo.com
}

\begin{abstract}
The following work deals with the problems of infections of a variety of fruit trees plants met in the Southern Region of Albania. In the analysis one of the most specific groups of plant-entomologists has been obtained, that of the U / Order Coccidia Class Insecta. These insects represent a specific set of pests that feed on plant lymphoma through a highly developed oral drip type suppressor. In this way they not only mechanically damage the plant but also convey it to many viral illnesses in the lymph, leading it to complete degradation. They are so closely related to the plant that, most of them, even wintering (one of the most delicate periods for plant survival itself) passes like parasites on them. Through this work, it is shown which of these entomophytes have met in this plant group in the region concerned? Which of the plant species analyzed is found most frequented by this group of pests and what is the spread of this contamination in both variety and percentage; also by analyzing the distribution of plant species encountered, at different altitudes over sea level? The paper contains, figuratively, a series of morpho-determining features of the representatives cited in this paper.

Given that this plant group is one of the main sources of vitamins for vegetarian foods for mankind, this work itself takes on importance and practical value.
\end{abstract}

Keywords: fruit trees plants, parasites, contamination, pests, varieties, spreads.

\section{Introduction}

The insects that belong to $U$ / Order Coccoinea represent a very specific group both from their way of feeding and form and body size. There are some strong and specialized types connected to a certain kind of plant from which they take their name such as: Lepidosaphes ficus Sign (affecting the fig) or Saisetia oleae Bern (affecting the olive), etc. There is also microscopic forms (the majority part) and forms that can be easily noticed [1-5]. In both cases, the determination of these U/Order representatives is difficult, especially with the microscopic forms. They are characterized by the presence of a strong oral-jaw apparatus of the type sting-suck,

On this basis, the damage of the plants consists on these effects (Fig. 1).

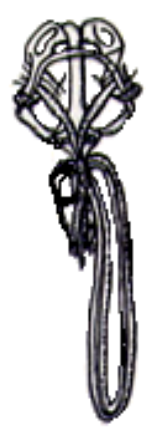

Fig. 1. Oral apparatus of drilling-suction type

1. Sucking the plant lymph by weakening it.

2. Deforming the leaves and buds of the plant until they break, so the efficiency of the photosynthetic process falls off.

3. By sucking the plant lymph, the insects can transmit a number of different viral diseases to the plants. 
4. Given that they produce what is called "honey dew", they become the main factor of different fungal plant diseases. Through this "honey dew" they also attract and make possible the placing of numerous types of Aphids or other parasites on the plant. In this way, a contaminated plant is threatened by three groups of pathogenic creatures simultaneously.

5. On this basis, the plant quality and quantity reduces until it withers and then fades completely.

However, the level of damage is not the same to all the types. There are strong direct pests, usual pests and lighter forms of parasitism (indirect pests) [6-11].

\section{Material and methods}

This study has been conducted based on a research related to the group of insects in the South Region of Albania. For this reason, a lot of field expeditions have been conducted for a period of over 10 years (with interruptions). The material has been gathered periodically in each checkpoint, for each season and year. The material cumulated in area by different plant bodies was preserved in samples with alcohol and their relevant label. For microscopic forms, the material, before undergoing determination process, was refined in the lab until it was reached a permanent micro preparation according to the method of [12-16]. Afterwards, the determination of species was made according to the keys given by [17-23], etc.

The region in word has some checkpoints placed in Vlora, Saranda, Delvina, Gjirokastra, Tepelena and Përmet (Fig. 2). During the research with binoculars, there are also compiled the sketches of their morphological features, especially of their most important part in the determination plan which is the pygidium.

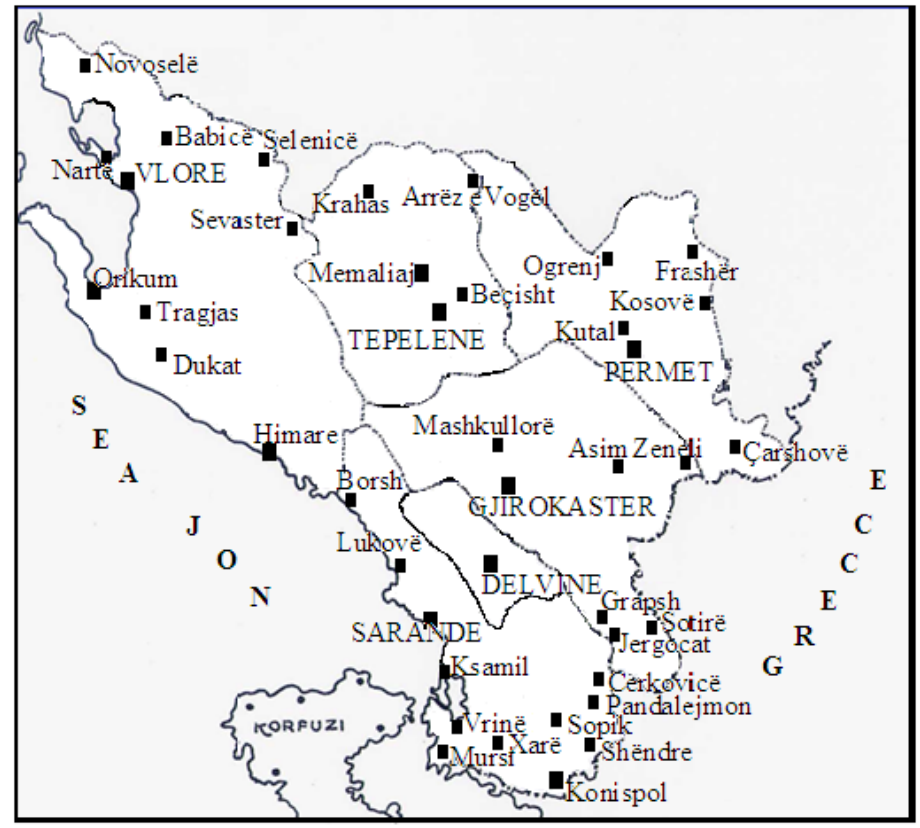

Fig. 2. Points - checks on terene

\section{Discussions}

The whole gathered material after being processed in the lab according to the methods described in literature [12-16], etc. was shaped in permanent microscopic preparations.

Afterwards, with the help and definitions used in the literature [17-20, 24, 25], etc. the determination of the kinds was made possible. Working under binoculars, which was very difficult and important, there were also compiled the morphological sketches of the creature itself, especially the most important part such as their pygidium where a variety of waxen glands, anal rings according to the type, spikes in the marginal path, pieces $\left(\mathrm{L}_{1}, \mathrm{~L}_{2}\right.$, etc), crests $(\mathrm{k})$, hairs (q), denzarcet (d), paraphysa (p), cylindrical glands (gj.c.), anal glands (gj.a.), anal ring (u.a.), etc., (Fig. 3) [4, 5, 13, 15, 18, 25], etc. 


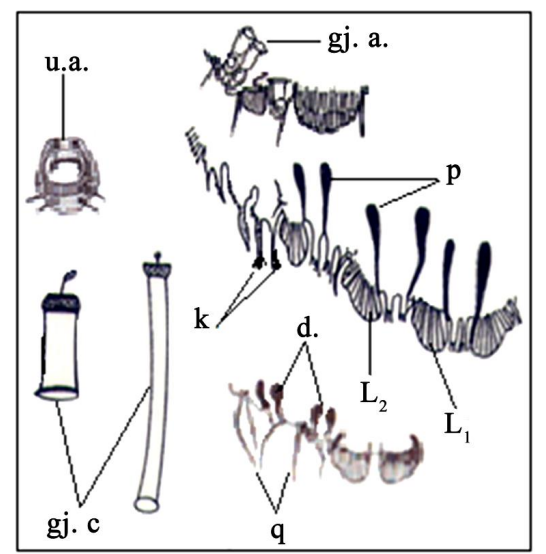

Fig. 3. Determinative elements of the pygidium

The elements mainly placed in the pygidium area have a special determinative importance not only on the variety of forms among them, but also on the way of placement, preservation of symmetry on both sides of the pygidium, their size and combination they create.

The pygidium glands appear not only in cylindrical shape but also in other such as: fungal, tubular, disc, bottle shape, multicellular or three, five cellular etc. It is this diversity of elements that must be taken into consideration in order to determine the types as correct as possible. At this point, what is to be emphasized is not only their diversity but also their number which appears to be specific from type to type and has a unique value in defining them.

All the sketches made with binoculars are shown in the pages with pictures accompanying the Fig. 8, 9.

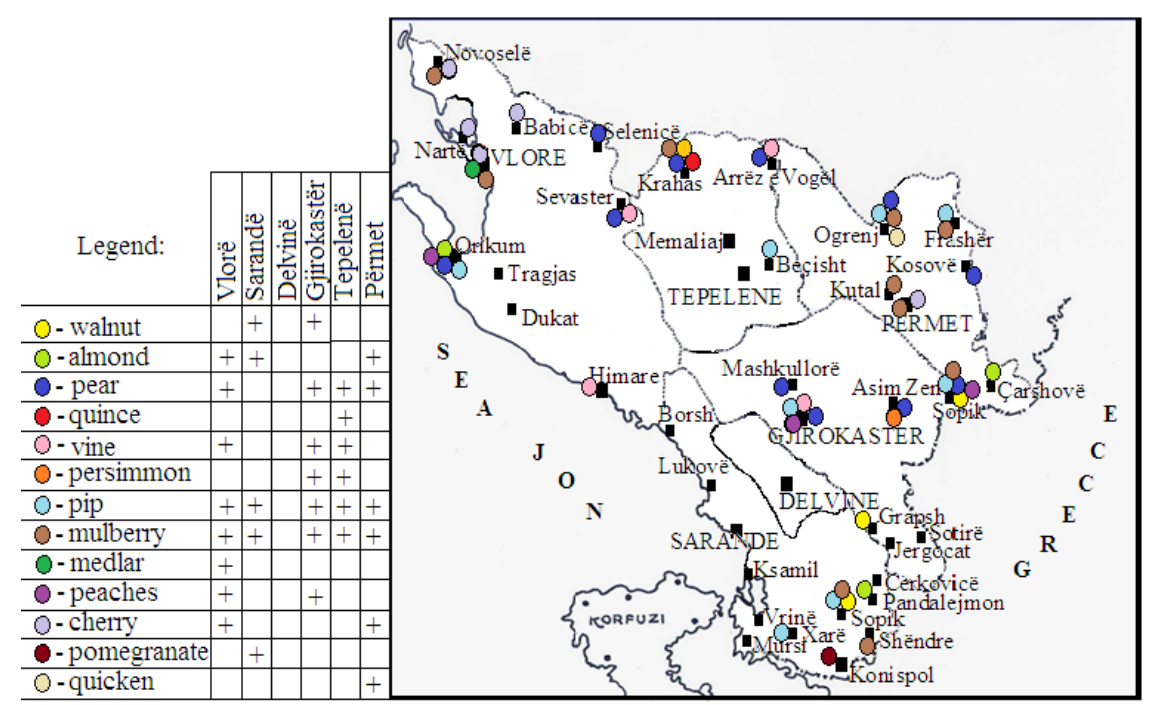

Fig. 4. Contaminated plant species in the concerned region

As it is seen in the Fig. 4, contaminated fruit trees by this insect have been found in five from the six regions being analyzed. In these areas, as it is shown in the corresponding map, the most affected is Vlora, followed by Gjirokastra, Tepelena, Përmeti and Saranda. The variety of damaging coccids, found and analyzed among all the plants being surveyed, is represented in the Table 1.

In this table it is obvious that during our research we have identified 26 kinds of parasites of this kind of plant. Looking at the symbols at the end of the table it is possible to see that from the group of plant parasites represented there is not any powerful direct harmer. There are 21 direct pests and a small amount of direct harmless species. (Coccus hesperidum L. (k.) [p, ms]), (Coccus 
pseudomagnoliarum Kuw. (k.) [p, sh, ms]), (Pulvinaria vitis L. (f) [sht]), (Eulecanium mali Schr. (k.f) [sht,j]) and (Carulaspis carueleii Targ.-Toz. (gj) [j]).

These species have been found in three of the main organs of the plant: stem, leaf and fruit.

Table 1

Variety of parasites found for each plant type

\begin{tabular}{|c|c|c|c|c|c|c|c|c|c|c|c|c|c|c|}
\hline \multirow[b]{2}{*}{ No. } & \multirow[b]{2}{*}{ Name of species } & \multicolumn{13}{|c|}{ The plant where it met } \\
\hline & & 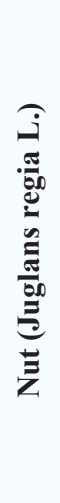 & 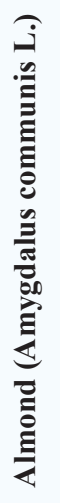 & 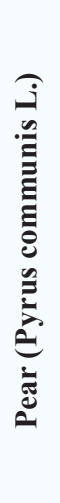 & 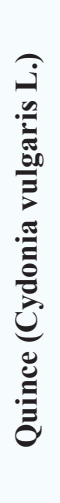 & 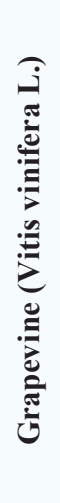 & 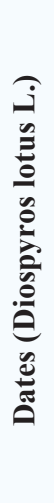 & 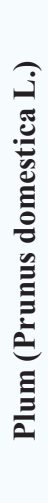 & 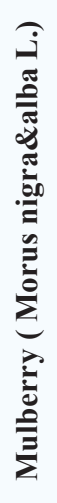 & 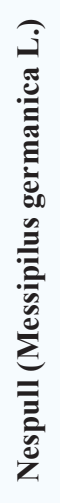 & 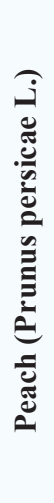 & 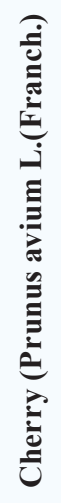 & 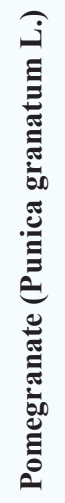 & 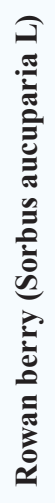 \\
\hline 1 & Coccus hesperidum L. (k.) [p, ms] & & & + & & & & + & & & & & & \\
\hline 2 & Coccus pseudomagnoliarum Kuë. (k) [p, sh, ms] & + & & & & & + & & + & & + & & & \\
\hline 3 & Parlatoria oleae Colv. (k) [j, ms, sh] & & + & + & & & + & + & & + & & & & \\
\hline 4 & Parlatoria thea Ckll. (k) [ms] & & & & & & & & & + & & & & \\
\hline 5 & Parlatoria cinerea Hadd. (k) [ms, j, sh] & & + & + & & & & + & & & + & & & \\
\hline 6 & Aonidiella aurantii Masc. (k.) [sh] & & & & & + & & & & & & & & \\
\hline 7 & Lepidosaphes gloverii Pack. (k) [ms] & & & & & & & & & + & & & & \\
\hline 8 & Lepidosaphes conchiformis Gmel. $(\mathrm{k})[\mathrm{m}]$ & & & & & & & & & & & & + & \\
\hline 9 & Pseudococcus adonidum L. (k.) [p] & + & & & & & & & & & & & & \\
\hline 10 & Chrysomphalus ficus Ashm. (k.) [j] & & & & & + & & & & & & & & \\
\hline 11 & Pseudaulecaspis pentagona Targ. (k.) [p, j.ms, sh] & & & & & & & & + & & + & + & & \\
\hline 12 & Paleolecanium bituberculatum Targ. (k) [ms, j] & + & & & & & & & + & & & & & \\
\hline 13 & Sfaerolecanium prunastri Fonce. (k) [sh] & & + & & & & & & & & & & & \\
\hline 14 & Ceroplastes rusci L. (k) [dh, j] & & & + & + & & & & & & & & & \\
\hline 15 & Epidiaspis leperii Sign. (k) [m, ms, j, sh, p] & & & + & & & & + & & & & & & + \\
\hline 16 & Diaspidiotus lenticularis Lndgr. (k) [ms] & & & + & & & & & & & & & & \\
\hline 17 & Diaspidiotus spurcatus Sign. (k) [j] & & & & & + & & & & & & & & \\
\hline 18 & Diaspidiotus perniciosus (ulmi) Comst. (k) [m] & & & & & & & + & & & & & & \\
\hline 19 & Pulvinaria vitis L. (f) [sht] & & & & & + & & & & & & & & \\
\hline 20 & Parthenolecanium rufulum Ckll. (k) [sh, j, m] & & & & & + & + & & + & & & & & \\
\hline 21 & Parthenolecanium corni Bouche. $(\mathrm{k})[\mathrm{j}, \mathrm{p}, \mathrm{m}]$ & & & & & & + & + & + & & & & & \\
\hline 22 & Parthenolecanium persicae F. $(\mathrm{k})[\mathrm{j}, \mathrm{m}, \mathrm{p}]$ & & & & & & & & + & & & & & \\
\hline 23 & Eulecanium mali Schr. (k.f) [sht, j] & & & & & + & & & + & & & + & & \\
\hline 24 & Eulecanium caragane Borch. (k) [p] & & & & & & & + & & & & & & \\
\hline 25 & Eulecanium rugulosum Ck1l. (k) [j] & & & & & & & & + & & & & & \\
\hline 26 & Carulaspis carueleii Targ.-Toz. (gj) [j] & & & & & & & & + & & & & & \\
\hline
\end{tabular}




\section{VO: A-Plant organ where the pest is found $(x)$}

- (k.)=stalk; - $(g j) .=$ leaf; - $(f)=$. fruit

\section{$\underline{B}$ - Explored regions}

- V.=Vlorë ; - GJ.=Gjirokastër; - T.=Tepelenë; - S.=Sarandë;

- P.=Përmet; - D.=Delvinë

\section{C-Months of the vear $[x]$}

$-j$, - sh, - ms, - p, - m, - q, - k, - g, - sht, - t, - n, - dh.

D-Damage

- ( Name)=not direct harmful species.

- $(*$ Name $)=$ direct harmful species.

- $\left({ }^{* * N a m e}\right)=$ powerful, direct harmful species.

Based on the annual duration during which these kinds can be found, let's state that they have been highlighted mainly from December to May and little in September. This might be because of the grown larva wintering as a result of that climate.

Data on how often these parasites can be found according to the plant type number or percentage are represented in the Fig. 6, 7 as follows.

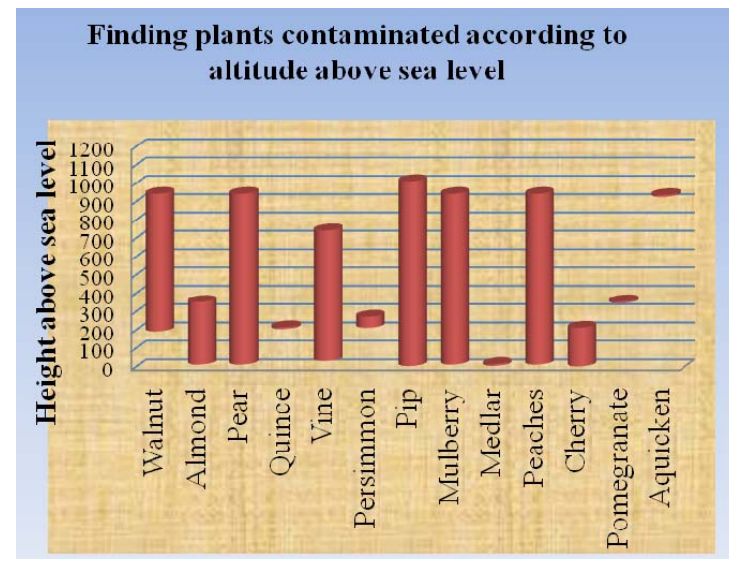

Fig. 5. Finding plants contaminated by altitude above sea level

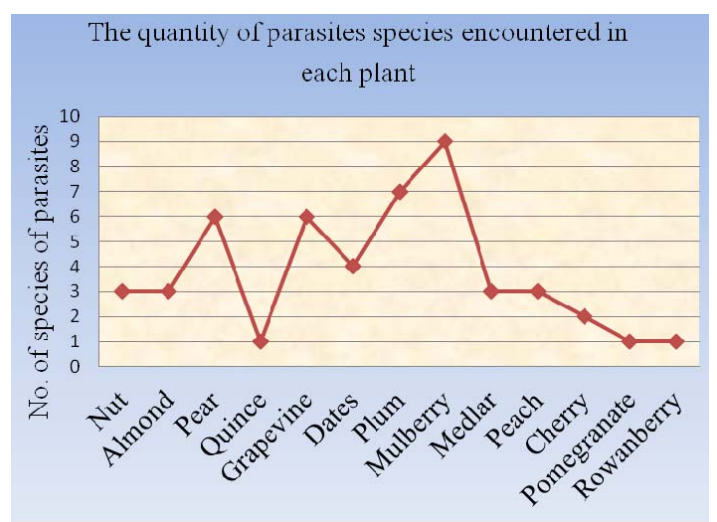

Fig. 6. The number of parasites encountered in each plant

In the Fig.7 the most preferable plant by many kinds of parasites is that of mulberry with 9 types, or $19 \%$ of the all parasites found in the region. After that, follows plum with 7 types, or $15 \%$ of the all types, pear and vine with 6 types or $12 \%$ of the total, date with 4 types or $8 \%$ of the total, nuts, almond, peach and medlar with 3 types or $6 \%$ of the total, cherry with 2 types or $4 \%$ and last the quince, pomergranate and quicken with 1 type or $2 \%$ of the total. Fig. 6 represents this kind of contamination. 


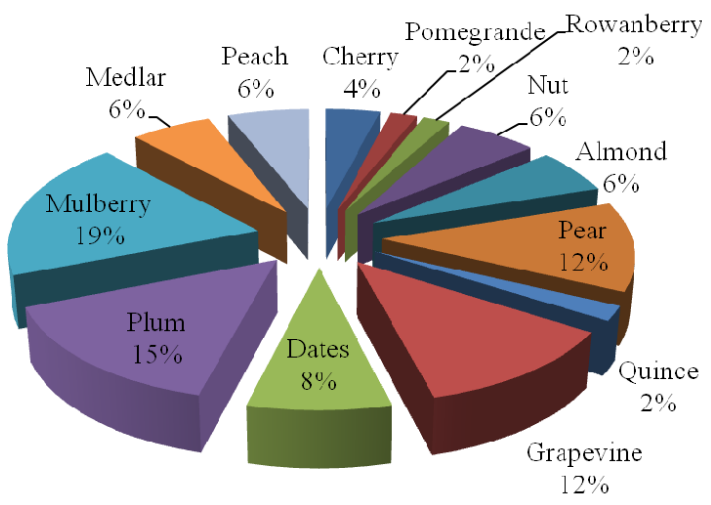

Fig. 7. The number of parasites encountered in each plant expressed in percentages

According to the Fig. 5, the plum is the most preferred fruit by these parasites in all its spreading in different heights above the sea level from $20-1020 \mathrm{~m}$. The following fruit trees are nuts, pear, mulberry and peach with a level from 20-950 m above the sea, vine with 40-750 m above the sea level, etc. In heights tightly restricted (very high or very low) have been found the quicken $(940 \mathrm{~m})$, the pomergranate $(360 \mathrm{~m})$, the quince and the date (in 220 and $280 \mathrm{~m}$ ) and in lower levels the medlar (in $20 \mathrm{~m}$ ).
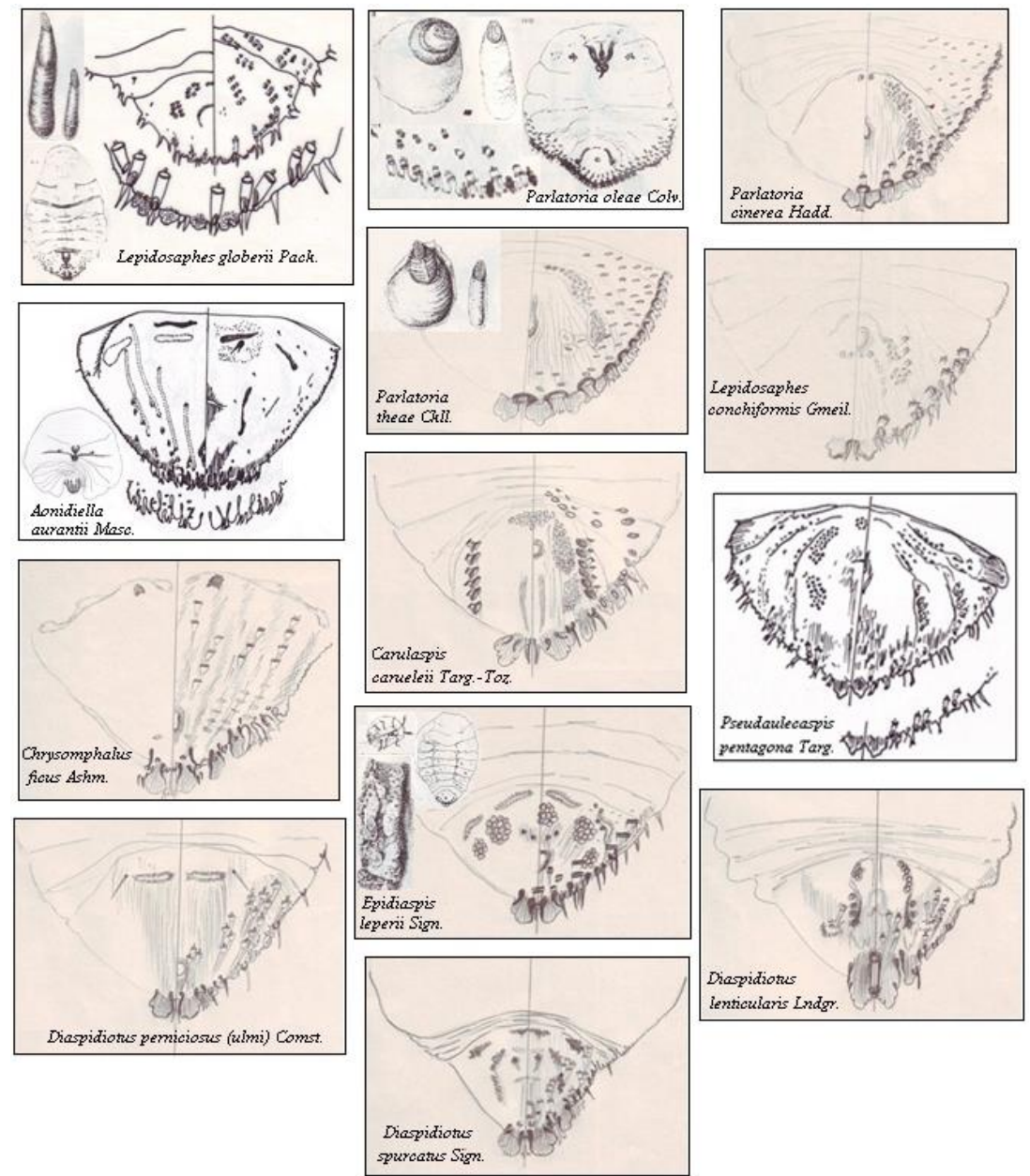

Fig. 8. Summary of pygidium sketches (under binoculars) of some species as well as some morphological sketches of some others sketches made by us, mainly sub binocular and that present determinant features of pygidium for each type 

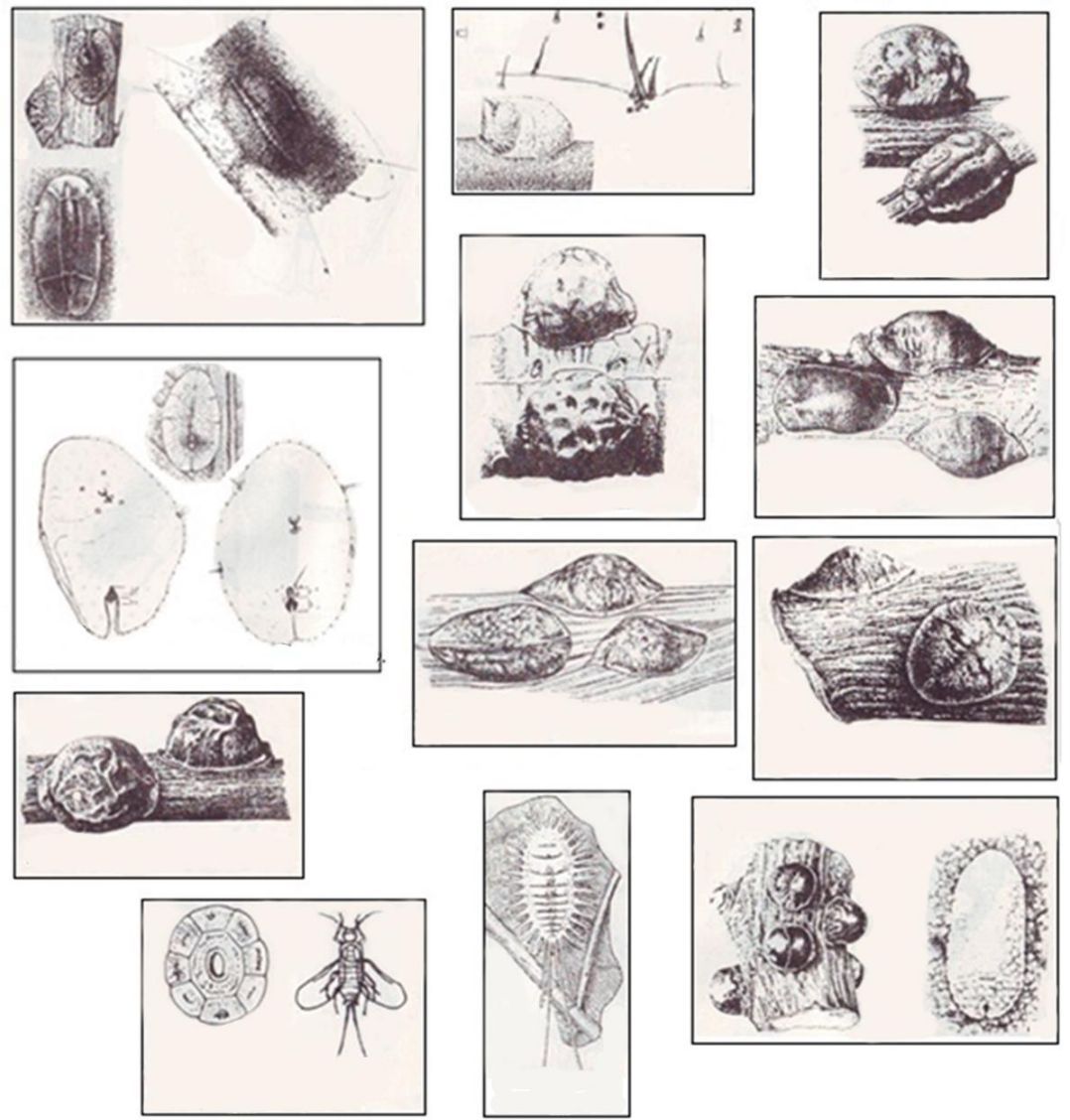

Fig. 9. Summary of pygidium sketches (under binoculars) of some species as well as some morphological sketches of some others. Morphological sketches of some other species of this fund

\section{Conclusions}

Based on the abovementioned data there are following conclusions:

1. As is observed in Table 1, in the entire investigated regions, there are a total of 26 types of parasites for this plant group. As for the symbols displayed at the end of this table, it is possible to see that out of the plant group analyzed in it, there is no encountered specie as a direct and powerful harmful one. There are 21 species as direct harmful ones, and a small minority as non-direct harmful species (Coccus hesperidum L. (k.) [p, ms]), (Coccus pseudomagnoliarum Kuw. (k.) [p, sh, $\mathrm{ms}]$ ), (Pulvinaria vitis L. (f) [sht]), (Eulecanium mali Schr. (k.f) [sht, j]) dhe (Carulaspis carueleii Targ.-Toz. (gj) [j]).

2. The whole spectrum of these fruit trees is found as contaminated by this harmful group, being either cultivated plants in areas of Mediterranean climate or existing even in the wild (as for example: Rowan berry) (Fig. 4, 5).

3. These parasites do not possess the same preference for all the plants. Thus, the most preferable for them we have found out are that of Mulberry with 9 types or $19 \%$ of all parasites encountered in this region. Next is the Plum with 7 types or $15 \%$ of all types, the Pear and Grapevine with 6 types or $12 \%$ out of the total, the Date with 4 types or $8 \%$ out of the total, Nuts, Almonds, Nespull and Peach with 3 types or $6 \%$ and then in turn the Cherry with 2 or $4 \%$ and finally the Quince, Pomegranate and Rowan berry with 1 type each or $2 \%$ of the total. (Fig. 6, 7). This preference occurs due to the food desirability of these parasites finding in the lymph of these plants.

4. In some plants there is a wide range of contamination for their spread in heights above sea level, in some others not. Let's take into consideration in this case the fact that such plants as the Plum are frequented by these types of parasites in the whole spectrum of spread in various heights with 20-200 m above sea level. Further, there are plants like Nuts, Mulberry and Peach with 20$950 \mathrm{~m}$ above sea level, Grapevine with 40-750 m, etc. In rather limited heights (either rather high or 
rather low) are encountered mainly Rowan berry (940 m), Pomegranate (360 m), Quince and Dates (at 220 and $280 \mathrm{~m}$ ) and the lowest Nespull (at $20 \mathrm{~m}$ ).

Considering the fact that the number of the encountered types in the last plants in very small in proportion with other plants let's come to the conclusion that types which frequent these plants the most adapted and closely linked with the plant as well as possessing a climate independence in therms of their territorial spread (Fig. 5).

5. Although the parasites have been found in the three main organs of the plant (the stalk, leaves, fruit), what notice is that the stalk is the most preferable plant organ frequented by them (Table 1).

6. Based on the Fig. 4 let's notice that contaminated fruit trees by this insect group are only in 5 out of six district of the region under analysis. In the region of Vlora are encountered a total of 8 types, in Gjirokastra 7 types, in Tepelena and Përmet 6 types in each of them, Saranda 5 types and Delvina with no type, which indicates that their spread is not determined by the coastal climate. If so, it is possible to found out more types than in the case of Përmet, which has not proved to be so. This also comes from the fact that the expeditions in this region have been considerably less frequented than the in other regions of the territory in question. This is also proved by the wide presence of these pests in citrus in this region.

7. Encountering of these parasites mainly in the period from December to May shows that creatures overwinter along with the plant. With reference to the fact that during their life cycle the movable larva gets out of the eggs that evolve up to three generations (I-III), according to the types, till the unmovable imagos, absence or not contacting them by the end of spring and summer is relevant to the movable larva stage. These non-static states as well as their microscopic forms do not give access to identify and collect them. The imago forms got (in winter) and the just-opened forms from imagos (spring time) enable their collection process [26].

\section{Recommendations}

1. According to propounded above, special care should be taken about the cultivated plats in the Mediterranean-coastal climate zones (Vlora, Saranda and Delvina) because the microclimate favors the development of parasites. In the case of parasites which are specifically connected with the plant (the case of Plum) this care should be taken throughout the whole year.

2. The vegetation, in all this territory, should be kept under control even during the season of winter when the time of low temperatures the insects are no more active or even under the condition of diapause.

3. In the case of this plant group, the chemical struggle is not the most acceptable option as we have to do with products being consumed in their natural state. In such circumstances, biological struggle would be the ideal thing, although it is impossible to carry it out massively. This is not only because of the cost or possibilities, but connected with a comprehensive knowledge and the possibility of cultivation of their natural enemies. However, it is recommended that the chemical struggle should be precisely undertaken during spring season (before fructification, when the insects themselves are in a movable larva stage), because their attachment under their cover makes this struggle ineffective and harmful to the product quality. For the region of Vlora, Saranda and Delvina this should start from March to April, while for the regions of Gjirokastra, Tepelena and Përmet, it should begin almost a month later (April to May).

4. In several cases the struggle against them consists of their treatment (dying) their new stalks with oil in order to prevent the new larvas to be attached there to overwinter, [27]. This should be done in September-October for the regions of Gjirokastra, Tepelena and Përmet and in the period October-November for the regions of Vlora, Saranda and Delvina.

\section{References}

[1] Balashovski, A., Mesnil, L. (1935-1936). Les insektes. Nusibles auks kultivees Vol. I-II. Paris.

[2] Baçi, M. (1954). Dëmtuesit kryesor të kulturave të arave e atyre frutorë. Tiranë.

[3] Borhksenius, N. S. (1949). Fauna SSSR. Nasjekomij e hobotni. Vol. VII Pogotr. çjervjeçij i shçitovki (koksoidea) sjemjejstvo muçnistije çjervjeçi (Pseudokoksidae). Moscow, 384. 
[4] Hasani, N. L. (1997). Koksidet. Tiranë.

[5] Illjustrirovanij spravoçnik po vreditjeljam i boljeznjam vnjeshn jevo karatina (1948). Minihsterstvo Sjellskovo Horjajstva SSSR, Otdjell po - Karantini Sjelskohozjajstbjennih Rastjenij, Çentralnaja Llaboratorija po Karantini Sjelskohozjajstbjennih Rastjenij. Mocow.

[6] Grafton-Cardwell, B. (2002). Stages of the Cottony Cushion Scale (Icerya purchasi) and its Natural Enemy, the Vedalia Beetle (Rodolia cardinalis). University of California. doi: https://oi.org/10.3733/ ucanr.8051

[7] Borhksenius, N. S. (1957). Fauna SSSR. Nasjekomije hobotni. Vol. IX Pogotr. çjervjeçi i shçitovki (koksoidea) sjemjestvo podushjeçnshçi i llozhnoshçitovki (koksidae). Moscow.

[8] Çiça, A. (1963). Kultura e kumbullës. Tiranë.

[9] Çeloaliaj, Q. (1987). Speciet e breshkëzave të përhapura në agrume në zonën e Vlorës e Sarandës. Instituti i agrumeve dhe ullirit. Vlorë.

[10] Gaxho, S. (1965). Kontribut në studimin e breshkëzës së kuqe të agrumeve. (Chrysomphalus dictyospermi Morg.) dhe mbi disa prova të luftimit të saj. BUSHT. Seria e Shkencave Natyrore No. 3. Tiranë.

[11] Murra, X. (1960). Vëzhgime mbi breshkëzën e fikut (Ceroplastes rusci L.). BUSHT. Seria e Shkencave Natyrore No. 3. Tiranë.

[12] Borol et, D. L. (1950). Përpunimi i breshkëzave. Lonon.

[13] Borhksenius, N. S. (1950). Sbor i izuçienije çjervjeçov i shçitovok. Moscow.

[14] Borhksenius, N. S. (1950). Çervjeçij i shçitovki SSSR (Koksoidea Opredjelitjeli po faunje SSSR, izdavajemije. Zoologiçjeskim institutom Akadjemii Nauk SSSR No. 32.1. Moscow.

[15] Borhksenius, N. S. (1950). Çjervjeçi i shçitovki SSSR (koksoidea). Moscow.

[16] Kosta, C. B. (1981). Radha e punës për përgatitjen e mikropreparateve entomologjike. London.

[17] Borhksenius, N. S. (1964). Oprjedjelitjel nasjekomih evropjejskoi çasti SSSR. Vol. I. Moscow.

[18] Borhksenius, N. S. (1949). Oprjedjelitjel çervjeçi i shçitovki (koksoidea). Erjevan.

[19] Borhksenius, N. S. (1937). Oprjedjelitjel koksid (koksidae) vrjedjashçik kulturnim rastjenijam i ljesu. Vol. II. Moscow.

[20] Borhksenius, N. S. (1973). Praktiçjeskij oprjedjelitjel koksid (Coccoidea) kulturnih rastjenij i ljesnih porod SSSR. Leningrad.

[21] Rubcov, I. A. (1954). Vrjeditjeli citrusovih i ih jestjestvjenije vragi. Moscow.

[22] Oprjedjelitjel nasjekomih evropjejskoj çasti SSSR. Vol. I. Nizshije, drjevnjekrilije, snjepolnim prjevrashçjenijem (1964). Akademija Nauk SSSR, Zoollogiçjeskij Institut. Mocow-Leningrad.

[23] Oprjedjelitjel nsjekomih evropjejskoj çasti SSSR (1948). Akademija Nauk SSSR, Zoollogiçjeskij Institut. Moscow.

[24] Arhangelskaja, A. D. (1974). Koksidi arjednjej Azii Tashkjent. Moscow.

[25] Borhksenius, N. S. (1966). Katalog shçitovok (Diaspidoidea). Mirovoj fauni. Moscow-Leningrad.

[26] Kaltani, T., Stani, A. (1973). Sëmundjet dhe dëmtuesit e ullirit, agrumeve, fiqve, kajsisë dhe nespullës. Tiranë.

[27] Qafa, E. (1957). Eksperienca jonë në luftimin e dëmtuesëve kryesorë dhe mbrojtja e fiqve. Tiranë. 